\title{
Correction: Detecting depression among adolescents in Santiago, Chile: sex differences
}

\author{
Ricardo Araya ${ }^{1 *}$, Jesus Montero-Marin ${ }^{2}$, Sergio Barroilhet ${ }^{3}$, Rosemarie Fritsch ${ }^{4,5}$, Jorge Gaete ${ }^{3}$ and \\ Alan Montgomery ${ }^{1}$
}

\section{Correction}

While compiling the article describing sex differences on depression among adolescents in Santiago, Chile [1], one of the authors was inadvertently omitted from the author list. This author, Jorge Gaete, has been included in the corrected author list above.

\begin{abstract}
Authors' contributions
$\mathrm{RA}, \mathrm{AM}$, and RF conceived the study and led the bid to secure funding for this work. JM-M analysed the data. SB, RF and JG were responsible for the fieldwork. RA and JM-M wrote the first draft. All authors read and approved the final manuscript.
\end{abstract}

\section{Author details}

'School of Social and Community Medicine, University of Bristol, Oakfield House, Bristol BS8 2PS, UK. ²Department of Psychiatry, University of Zaragoza, Zaragoza, Spain. ${ }^{3}$ School of Psychology, University of the Andes, Santiago,

Chile. ${ }^{4}$ Department of Psychiatry and Mental Health, University of Chile Clinical Hospital, Santiago, Chile. ${ }^{5}$ Department of Psychiatry, Faculty of

Medicine, University of the Andes, Santiago, Chile.

Received: 8 October 2013 Accepted: 8 October 2013

Published: 18 October 2013

\section{Reference}

1. Araya R, Montero-Marin J, Sarroilhet B, Fritsch R, Montgomery A: Detecting depression among adolescents in Santiago, Chile: sex differences. BMC Psychiatry 2013, 13:122.

\footnotetext{
* Correspondence: riaraya.psych@gmail.com

${ }^{1}$ School of Social and Community Medicine, University of Bristol, Oakfield House, Bristol BS8 2PS, UK

Full list of author information is available at the end of the article
}

\section{Submit your next manuscript to BioMed Central and take full advantage of:}

- Convenient online submission

- Thorough peer review

- No space constraints or color figure charges

- Immediate publication on acceptance

- Inclusion in PubMed, CAS, Scopus and Google Scholar

- Research which is freely available for redistribution

Submit your manuscript at www.biomedcentral.com/submit 